\title{
DANO MORAL CAUSADO POR PROGRAMAÇÃO DE TV AO PÚBLICO INFANTO-JUVENIL: mecanismos de tutela judicial
}

\author{
MORAL DAMAGE CAUSED BY TV PROGRAMMING TO CHILD AND YOUTH PUBLIC: forms of \\ juridical assistence
}

Antonio Jorge Pereira Júnior ${ }^{1}$

\begin{abstract}
Resumo:
O serviço público de radiodifusão audiovisual - a televisão - tem o dever legal de colaborar com a formação ética e social da população infanto-juvenil em todos os serviços que presta. Quando a televisão descumpre esse dever, recai em ilícito e produz danos que autorizam medidas judiciais. $\mathrm{O}$ artigo trata da lesão moral causada à criança e ao adolescente por programação de TV e de alguns modos de reação judicial em face do abuso da mídia televisiva no Brasil.
\end{abstract}

Palavras-chave: Dano moral. Criança e adolescente. Direito de formação integral. Tutela inibitória. Televisão. Defesa do consumidor. Ilícito comunicativo. Ação civil pública.

\begin{abstract}
:
The public service of audiovisual difusion - the TV - has the legal duty an collaborate to the ethical and social education of the children and youth population in every service it pays. when the TV violates this duty, it commits an ilicit and produces damages that authorise juridical acts. The papers aims the moral damage caused to child youth people by television programming and some juridical ways of reaction face the abuse of television media in Brazil.
\end{abstract}

Keywords: Moral damage. Child and youth people. Right to the integral education. Television.

\section{Introdução}

Em tese defendida na Faculdade de Direito da Universidade de São Paulo, concluiu-se que as empresas de radiodifusão integram o sistema protetivo dos direitos da criança e do adolescente. São abundantes as normas que ratificam esse entendimento. Decorrência desse postulado é o entendimento de que a TV deve colaborar ativamente na formação ética das novas gerações. O contrário disso é desconstruir a personalidade e colonizar a mente e o caráter com idéias e atitudes limitadoras da realização pessoal e redutoras da dignidade do telespectador.

A integridade moral da criança e do adolescente é objeto de proteção em variados dispositivos do Estatuto da Criança e do Adolescente. Mas, para a correta

\footnotetext{
1 Doutor em Direito Civil pela Faculdade de Direito da Universidade de São Paulo.
} 
compreensão de como se processa lesão na personalidade infanto-juvenil, é preciso avançar na exposição do conceito de modo a reconhecer o dano mesmo que esteja ausente a percepção da criança, em razão de carecer de auto-imagem e de discernimento maduro para dar-se conta do dano.

Além da revisão e proposição de entendimento para a noção de dano moral, o presente artigo - que traz muito do capítulo final da tese de doutoramento acima indicada, preservando mesmo parte do texto original - anota medidas judiciais e argumentos concretos que podem servir para a exigência dos direitos do público infanto-juvenil lesado por programação televisiva.

2. Dano moral como afetação da capacidade de se autodeterminar

Na correta conceituação de Walter Moraes "dano moral é, tecnicamente, um não-dano, onde a palavra 'dano' é empregada com sentido translato ou como metáfora: um estrago ou uma lesão (este o termo jurídico genérico), na pessoa, mas não no patrimônio". A expressão "dano", para ele, refere-se à lesão material. Por isso entende inapropriado o termo "dano moral". Mais adequado seria falar-se em lesão moral ou lesão imateria, que pode afetar diversas dimensões da constituição espiritual humana. Apesar de se estar de acordo com Walter Moraes, manter-se-á nesse trabalho o uso do termo dano moral, por força da vulgarização do termo no meio jurídico.

Ainda segundo o Walter Moraes, o termo moral foi adotado no Brasil por força da doutrina francesa onde "moral se diz tudo quanto não é patrimonial ou econômico nem material, como se o econômico e o físico não entrassem no campo da moral". Savatier, por exemplo, entende dano moral como "todo sofrimento humano que não resulta de uma perda pecuniária" e inclui como causa de dano moral todo evento contrário à reputação, à legítima autoridade, ao pudor, à segurança e tranqüilidade, ao amor-próprio estético, à integridade da inteligência, às afeições da vítima, etc.

Gilberto Haddad Jabur conceitua dano ou prejuízo como "perda ou afetação de bem revestido de proteção jurídica", e pode "atingir as coisas ou espírito humano".

E quais seriam os eventos que gerariam alguma lesão imaterial à criança e ao adolescente? Como identificar um dano moral em quem não tem plena capacidade de perceber a lesividade de um ato imaterial?

$\mathrm{O}$ recurso à etimologia pode oferecer uma pista a essa questão. O termo mores, latino, tem par com o grego ethos e se refere ao comportamento humano livremente querido, dirigido a um bem que aperfeiçoa aquele que o pratica, e o torna humanamente 
melhor. O conceito de mores não se identifica plenamente com o de costume, conceito que significa decantação de um hábito, independentemente de sua qualificação ética. A moral traz a dimensão positiva da conduta humana. Assim também a palavra ethos, de onde nasceu o termo Ética, a ciência do bem viver, segundo Aristóteles, o pai da Ética. Ou seja, mores e ethos trazem notícia da virtude. Por isso, o dano moral será o dano que, antes de se traduzir como afetação da dimensão afetiva ou da auto-imagem, é lesão que afeta a conduta orientada a valor - a liberdade da pessoa, compreendendo-se com tal palavra a capacidade de se autodeterminar para o bem.

Observando algumas das causas de danos morais, segundo Savatier - evento contrário à reputação, à legítima autoridade, ao pudor, à segurança e tranqüilidade, etc percebe-se na base de todas elas um ato injusto que gera inibição na capacidade de agir ou julgar ou altera o curso de atos da pessoa que é vítima, por efeito reflexo. O dano moral seria, dessa forma, o ferimento de um bem intangível - no fundo, a liberdade para agir - que repercute na capacidade de julgar, decidir e agir. Nessa perspectiva se pode avançar para a compreensão mais profunda do dano moral infanto-juvenil e mesmo do dano moral do adulto.

Um dano moral costuma ser reconhecido, primeiramente e de modo mais habitual, pela manifestação provocada na dimensão emotiva da pessoa. Isso se dá porque os sentimentos são tipos de juízos de correspondência entre uma realidade real (objetiva) ou aparente (subjetiva) e a sensibilidade de alguém. O sentimento de medo, por exemplo, denuncia uma situação de alerta para a pessoa, que repercute em sua capacidade de decidir, de julgar e agir. Exista ou-não um perigo real, a pessoa sente como existisse e adota uma conduta objetiva de "cuidado". Ou seja, há uma construção racional subjacente no sentimento humano: os afetos do ser racional guardam em si uma racionalidade.

$\mathrm{O}$ dano moral se manifesta em reações emotivas quando na pessoa se processa essa correspondência entre a dimensão sensitiva e sua realidade (real ou aparente), interior ou circundante. Desse modo, a percepção sensível denuncia inibição da conduta da pessoa. Por exemplo, a calúnia pode ser causa de dano moral na medida em que leva uma pessoa a se retrair em razão do efeito provocado por uma maledicência. Mesmo uma pessoa menos sensível, e que sofra menos com o impacto da calúnia, será vítima de dano moral. Neste caso, a percepção do efeito circundante que limita o raio de ação pessoal é suficiente para denotar existência de dano moral.

Por exemplo, uma pessoa, que foi cadastrada equivocadamente como mápagadora no Serviço de Proteção ao Crédito, pode sentir-se lesada em sua auto-imagem e em sua reputação, fato que lhe gera desconforto íntimo, percebido primeiramente em sua dimensão afetiva, desencadeando efeitos no seu sistema volitivo - em sua motivação - para 
algumas atividades, alterando-se suas disposições para certas atitudes. Nesse exemplo, o dano moral repercute na dimensão sensitiva e por meio dela é primeiramente percebido. Mas, independentemente do grau de afetação da sensibilidade, pode-se constatar dano moral, na medida em que a pessoa sofrerá uma alteração de sua imagem perante terceiros que poderão consultar o SPC e formular juízo equivocado sobre sua pessoa.

\section{Dano moral causado à criança e ao adolescente}

A criança ainda não tem um referencial ético completo e sua sensibilidade não faz com perfeição a correta correspondência entre bons sentimentos e boas condutas e vice-versa, ou seja, não associa com perfeição os afetos desagradáveis às atitudes eticamente reprováveis. Aliás, a finalidade da educação moral é exatamente educar para as virtudes, para a correta percepção do que realiza e faz autenticamente feliz a pessoa. Em razão da dificuldade de discernir o plano dos prazeres (sensações) do plano da felicidade ética decorre a facilidade em induzir o comportamento infantil com doces e prêmios que agradam, mesmo quando dados como pagamento de condutas reprováveis, que por vezes deformam o caráter da pessoa. Quantas crianças são aliciadas mesmo sexualmente em razão dessa situação de vulnerabilidade. O dano moral dar-se-ia, nesses casos, quando se estimulam condutas prejudiciais à formação ética, na medida em que estimulam a agir e julgar em desacordo com a melhor opção para sua realização.

Criança e adolescente sentem natural atração pelos prazeres e precisam de exemplos de conduta. Nesse contexto, a TV pode colaborar com sua formação, por meio de programas atrativos que promovam modelos de comportamento valorativo, ou pode apresentar programação na qual predomine atitudes violentas ou sensuais, que deleitam os sentidos e, ao mesmo tempo, estimulam condutas inadequadas, distantes de valores que seriam pertinentes ao melhor interesse da criança. Quando a TV projeta sensações que direcionam o comportamento para atitudes não adequadas à formação ética, ela opera um dano à dimensão afetiva - pois gerará afeição desordenada -, que passa inadvertido para a criança, em razão de ela não ter capacidade para discernir com propriedade o quanto aquilo lhe prejudica. Esse dano projetará má-conduta, ou seja, um dano ético, no sentido original do termo dano moral.

Pode-se avançar na relação direta entre dano e costume, uma vez que os estímulos negativos induzem a desejos e atitudes que podem danificar a esfera de volição e de hábitos de modo praticamente imediato, em razão da predisposição de imitação, e da inibição que certos atos podem produzir na criança, gerando-se propriamente dano moral, ou seja, prejuízo aos hábitos virtuosos e ao exercício da liberdade, que se torna refém dos vícios. 
Adimensão dos hábitos está intimamente relacionada ao exercício do poder de autodeterminação - liberdade. Para se autodeterminar, segundo padrão de comportamento adequado à dignidade humana, a pessoa deve ser bem instruída e estimulada a agir bem. A criança e o adolescente estão em estágio de evolução, passível de sofrer interferências de modo mais proeminente que uma pessoa adulta. Necessitam de estímulos e informações que potencializem o melhor uso de sua liberdade. Não dispõem de maturidade suficiente para agir bem diante das ofertas e estímulos que recebem na vida em sociedade. Por isso os pais exercitam em seu lugar certos atos da vida civil (representação jurídica durante infância) e depois lhes assistem na tarefa decisória (assistência jurídica na adolescência). A liberdade humana em evolução deve ser protegida. Exercita-se a liberdade, mormente, a partir do conjunto de informações das quais se dispõem. Por isso a instrução que chega mediante informação televisiva à criança vai interferir em seu modo de decidir e pode colaborar ou prejudicar seu modo de escolher.

A proteção dos direitos da criança e do adolescente exige a tutela da liberdade em formação, em evolução. Toda a sociedade está vinculada com essa formação, que perpassa pela integração dos estímulos afetivos, motivações e instrução que chega à pessoa menor de idade. Sem esse cuidado não se cumpriria a prioridade de atendimento sumarizada no art. 227 da Constituição Federal, dentro do título "da ordem social”.

Pode-se ler no Estatuto da Criança e do Adolescente, Capítulo II do Título II (Dos Direitos Fundamentais), que trata do direito à liberdade, ao respeito e à dignidade: "a criança e o adolescente têm direito à liberdade, ao respeito e à dignidade como pessoas humanas em processo de desenvolvimento e como sujeitos de direitos civis, humanos e sociais garantidos na Constituição e nas leis (art. 15)".

A lei reconhece a progressiva capacidade de decidir autonomamente da criança e do adolescente. Todavia, trata-se de capacidade de uma pessoa em processo de desenvolvimento, razão pela qual se lhe nega plena capacidade de agir. Confere-se-lhe maior aptidão para agir com autonomia no meio social à medida que se presume aprimoramento de seu discernimento no processo educativo. Ou seja, o processo decisório, com as fases de percepção, ponderação, decisão e responsabilização apropriada, amadurece com o tempo. É preciso que nesse período a criança e o adolescente recebam formação adequada para saber usar desses poderes ao raiar da maioridade, sob risco de abusarem de tais poderes de modo deletério para si mesmos e para a sociedade onde vivem.

$\mathrm{O}$ art. 18 do Estatuto da Criança e do Adolescente diz ser dever de todos velar "pela dignidade da criança e do adolescente, pondo-os a salvo de qualquer tratamento desumano, violento, aterrorizante, vexatório ou constrangedor". Ao mesmo tempo, no 
dispositivo que o antecede, o art. 17, está estabelecido que toda criança tem direito ao respeito, entendendo-se como tal "a inviolabilidade da integridade física, psíquica e moral da criança e do adolescente, abrangendo a preservação da imagem, da identidade, da autonomia, dos valores, idéias e crenças, dos espaços e objetos pessoais". A TV também deve respeitar a integridade moral e preservar os valores, idéias e crenças das crianças e adolescentes, sendo fato que muitos desses valores, idéias e crenças pessoais são herdados do entorno familiar e da sociedade circundante, de modo que esse dispositivo harmonizase ao dispositivo do art. 221, IV da Constituição Federal, de 1988, que estabelece que a programação televisiva deve respeitar os valores sociais e éticos da pessoa e da família.

Poder-se-ia, ainda, tratar de descrever os direitos de personalidade da criança e do adolescente ao nome, à intimidade e à imagem, evoluindo-se no entendimento das peculiaridades que se projetam nesses bens em face da criança. Todavia, esse tema não será aqui desenvolvido, pois comporta volume de estudo para outra tese.

Para se retomar de modo sintético a interferência nas três dimensões formativas, construiu-se um quadro esquemático, onde se podem identificar os objetos de atração de cada uma delas.

\begin{tabular}{|c|c|c|c|}
\hline ambitos de formação & Inteligência & Vontade & Afetividade \\
\hline $\begin{array}{l}\text { Ciência filosófica corres- } \\
\text { pondente }\end{array}$ & Gnoseologia & Ética & Estética \\
\hline Objetos de atração & Verdade & Bondade (Valores) & Beleza \\
\hline Atos próprios (exemplos) & $\begin{array}{c}\text { Conhecer, pensar, } \\
\text { ponderar }\end{array}$ & $\begin{array}{l}\text { Querer, decidir, delibe- } \\
\text { rar, amar }\end{array}$ & $\begin{array}{c}\text { Sentir, apreciar, delei- } \\
\text { tar-se }\end{array}$ \\
\hline Posturas reducionistas & Racionalismo & Voluntarismo & Sentimentalismo \\
\hline $\begin{array}{c}\text { Tipos de educação direta- } \\
\text { mente implicados }\end{array}$ & $\begin{array}{l}\text { Educação formal } \\
\text { (escolar) }\end{array}$ & Educação ética & Educação artística \\
\hline $\begin{array}{c}\text { Efeitos da carência de } \\
\text { formação }\end{array}$ & $\begin{array}{l}\text { Prejuizo da capacida- } \\
\text { de de compreender o } \\
\text { mundo e a si mesmo. }\end{array}$ & $\begin{array}{l}\text { Prejuizo no exercício } \\
\text { da liberdade e do } \\
\text { amor: querer fraco, } \\
\text { não dirigido a valores. }\end{array}$ & $\begin{array}{l}\text { Hipertrofia da busca de } \\
\text { prazer. Sobrevaloriza- } \\
\text { ção do ter sobre o ser. } \\
\text { Consumismo. }\end{array}$ \\
\hline $\begin{array}{c}\text { Associação próxima com } \\
\text { finalidades da } T V\end{array}$ & Informar & Educar & Entreter \\
\hline $\begin{array}{c}\text { Resultado da Formação } \\
\text { Integral }\end{array}$ & $\begin{array}{l}\text { Aquisiçâo de informa- } \\
\text { ções relevantes para } \\
\text { compreender-se e } \\
\text { compreender o mundo }\end{array}$ & $\begin{array}{l}\text { Desenvolvimento de } \\
\text { virtudes e do exercício } \\
\text { pleno da liberdade }\end{array}$ & $\begin{array}{c}\text { Educação dos afetos e } \\
\text { subordinação deles à } \\
\text { dimensão ética }\end{array}$ \\
\hline
\end{tabular}


A lesão moral à criança ou adolescente seria o resultado nocivo à sua personalidade decorrente da operação de fixação de idéias e valores que prejudiquem sua formação integral, em situação em que lhe seja difícil resistir às mensagens do emissor, dadas sua inexperiência, vulnerabilidade e sugestionabilidade. Quando a programação televisiva, de elevado poder persuasivo em face do público infanto-juvenil, promove a inclinação para comportamentos contrários ao bem-estar pessoal (vícios) e social (atitudes anti-sociais), ela causa lesão moral à criança e ao adolescente.

\section{O abuso da mídia televisiva: o ilícito comunicativo}

Em razão da situação do telespectador infanto-juvenil, a Constituição Federal determinou que a União classificasse os conteúdos da mídia eletrônica e os espetáculos, e estabelecesse horários adequados para seu oferecimento. A classificação de filmes e programas é indicativa para os cidadãos e consumidores, no âmbito privado, e a veiculação dessa informação é impositiva para os fornecedores desses serviços.

O Estatuto da Criança e do Adolescente, em atenção especial ao público infanto-juvenil foi taxativo no cumprimento do mandamento constitucional e carreou maior responsabilidade ao agente televisivo. Assim, o art. 76 determina que "as emissoras de rádio e televisão somente exibirão, no horário recomendado para o público infanto-juvenil, programas com finalidades educativas, artísticas, culturais e informativas", reforçando em seu parágrafo único que "nenhum espetáculo será apresentado ou anunciado sem aviso de sua classificação, antes de sua transmissão, apresentação ou exibição". Note-se a expressão somente, grifada aqui.

No art. 254, que reforça esse dever, considera-se infração administrativa “transmitir, através de rádio ou televisão, espetáculo em horário diverso do autorizado ou sem aviso de sua classificação", estabelecendo como pena "multa de vinte a cem salários de referência; duplicada em caso de reincidência; a autoridade judiciária poderá determinar a suspensão da programação da emissora por até dois dias”. Como se vê, não há espaço para os fornecedores de serviço de radiodifusão exercerem sua atividade em descompasso com os interesses da criança e do adolescente, público majoritário que lhe concede audiência.

O paradigma da proteção integral da criança e do adolescente, associado ao princípio de atendimento prioritário aos seus direitos (art. 227 da Constituição Federal de 1988), criou contexto onde se exige respeito qualificado de todos aqueles cuja atividade possa afetar seus direitos. A proteção integral cambiou a moldura tradicional dos abusos 
da mídia televisiva, assim como de todos aqueles cuja atividade gera riscos ao universo de direitos dos menores de idade. Será configurado como abusivo o exercício de atividade que não observe finalidades e limites com vistas a proteger interesses do público infantojuvenil.

Também é de grande importância o disposto no art. $3^{\circ}$ do Decreto n. 52.795, de 31 de outubro de 1963, que determina que "os serviços de radiodifusão têm finalidade educativa e cultural, mesmo em seus aspectos informativo e recreativo, e são considerados de interesse nacional, sendo permitida, apenas, a exploração comercial dos mesmos, na medida em que não prejudique esse interesse e aquela finalidade". Ou seja, a finalidade educativa cinge todos os demais serviços prestados pela mídia televisiva. Interesse nacional e finalidade educativa são condicionantes do serviço televisivo. Não ofertar serviço com esse caráter é desbordar dos limites exigidos por lei, e, logo abusar, o que pode significar, como se verá na seqüência, agir ilicitamente.

Essa situação impende também sobre aquele que oferta programas em horário voltado ao público infanto-juvenil, a quem se confia a finalidade de colaborar com a formação de criança e adolescente sem induzi-las ao consumo de bens, produtos e valores morais desconformes à sua necessidade pedagógica. Entrar no ar em horário dedicado à programação infanto-juvenil é assumir um risco e há dever reforçado de buscar o melhor interesse da criança em razão de a radiodifusão ser serviço público e de haver graves exigências constitucionais e infraconstitucionais em garantia da prioridade absoluta de atenção a esse público. Assim, o que é exibido na TV, em horário voltado ao público infanto-juvenil, e lhe prejudica a formação moral, pode ser caracterizado como ilícito comunicativo.

Além do flagrante desrespeito aos arts. 76 e 254 do Estatuto da Criança e do Adolescente, há outros modos de desobedecer os dispositivos legais. Os deveres jurídicos podem ser descumpridos por omissão ou comissão. A omissão importa inação, a permanência em um status quo que antecede a realização de prestação devida. Somente há omissão quando existe dever de agir conforme determinado comportamento juridicamente exigível. A comissão se dá pela atuação intrusiva e deletéria, lesiva, na esfera jurídica de outrem. Pode dar-se por palavras ou atos. É suficiente a violação do dever geral de abstenção para se configurar ilicitude.

Deveres morais malferidos também podem implicar conduta civil ilícita, porque o menosprezo a regras morais e aos hábitos saudáveis e por isso incorporados pela sociedade (bons costumes), além do procedimento contrário à lei e da ofensa de um dever nela não contido (dever geral), infunde 
comportamentos que, vez por outra, merecem reprovação jurídica.

Quando do ilícito resulta dano, material ou imaterial, entra-se no âmbito da responsabilidade civil, que disciplina a situação gerada por atos contrários a direito que causem danos, com ou sem culpa, fora da esfera penal.

Foram vistos à exaustão os deveres dos operadores de mídia televisiva em face da criança e do adolescente, integrados no sistema e na rede protetiva, tendo por escopo a formação integral e por referência modelar o que se exige com o poder familiar. Importa chamar a atenção ao momento de constituição do ilícito de modo a apresentar as vias judiciais para exigir retificação. Caso se reconheça a produção de dano, material ou imaterial, pode-se socorrer da disciplina da responsabilidade civil. Caso haja contrariedade a direitos, gerando-se risco de dano, mas ainda sendo difícil reconhecer algum dano, material ou imaterial, pode-se recorrer à tutela inibitória, prevista no $\mathrm{CPC}$, art. 461, em pedido autônomo, para impedir o desenlace lesivo.

$\mathrm{Na}$ mídia televisiva predomina a responsabilidade objetiva, pelas características: serviço público, concessão pública, potencialidade destrutiva da comunicação social de massa. O operador de mídia tem deveres agravados também pela potencialidade de lesar a formação da criança e do adolescente. A Constituição Federal quis carregar essa responsabilidade, cingindo o exercício dessa atividade a normas cogentes acerca dos conteúdos transmitidos.

Na perspectiva do Direito Civil, o Código, de 2002, permite compreender que se dá ato ilícito além das situações tradicionais de verificação de lesão material ou moral concreta (art. 186 do Código Civil, de 2002, doravante CC). Também quando o titular de um direito, no exercício do mesmo, desborda "manifestamente os limites impostos pelo seu fim econômico ou social, pela boa-fé ou pelos bons costumes" (art. 187 do CC) configura-se o ilícito. Não seria necessário, neste último caso, verificar-se lesão material ou culpa, sendo suficiente a assunção do risco de lesão, do perigo abstrato. Sobre esse fundamento legal se pode construir a figura do ilícito comunicativo, que afetaria a confiança, e que poderia ser perpetrado por um meio de Comunicação Social, em razão do desvio de finalidade.

O abuso dos meios de Comunicação pode se dar por quaisquer dos motivos descritos no art. 187: desrespeito a seu fim econômico ou social (o fim social é reforçado em razão de a radiodifusão ser uma concessão pública com finalidades indicadas pela Constituição Federal, de 1988), pela ofensa à boa-fé (todo o âmbito dos deveres laterais de conduta) ou pela conduta prejudicial aos bons costumes (conceito legal indeterminado 
cujo conteúdo será definido a partir da expectativa social). Nesses casos, como se deduz da lei, não há necessidade de comprovação de lesão material, imaterial ou culpa. Ultrapassar a finalidade dos poderes jurídicos outorgados, desrespeitar os deveres laterais de conduta e infringir os bons hábitos de convivência configuram atos ilícitos. Está-se no limiar entre Ética e Direito, na intersecção das duas ciências do comportamento humano. O ilícito, ausente o dano, não-gera responsabilidade, mas gera dever de interromper o ato.

O reconhecimento expresso da ilicitude pelo abuso demonstra evolução do Direito posto nacional, que incorporou o amadurecimento doutrinário levado a termo especialmente entre civilistas franceses e alemães, que inspiraram parte da doutrina pátria. De certa forma, poder-se-ia dizer que a infração dos limites dos poderes concedidos, em si, é uma espécie de lesão à ordem social. A lei não concedeu legitimidade - autorização de movimentação de determinada posição jurídica - para o abuso, senão para o adequado uso do direito, inserido em seu contexto social e jurídico. As exceções à imputação de responsabilidade pelo abuso estão enunciadas no art. 188 do Código Civil, de 2002.

A configuração normativa do abuso como ato ilícito, sem necessidade de verificar-se a intencionalidade do agente, facilita o recurso ao Judiciário. $\mathrm{O}$ abuso favorece a identificação da responsabilidade e pode se dar em quaisquer dos serviços específicos prestados pela mídia televisiva: notícias, entretenimento, atividade de caráter eminentemente educativo. A simples fofoca sobre intimidade alheia, por exemplo, pode configurar abuso e gerar lesão moral.

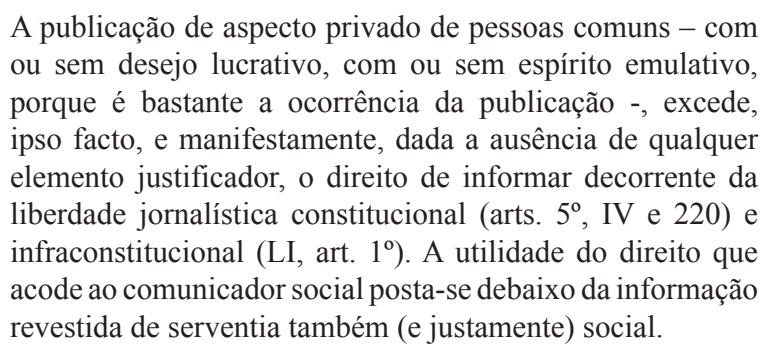

Outro bem imaterial que pode ser lesado com o abuso é a confiança. $\mathrm{Na}$ relação que se estabelece entre empresas de televisão e telespectadores, há dever de lealdade da emissora de TV, e essa lealdade comporta o cumprimento das exigências legais acerca dos conteúdos. Em princípio, espera-se que o serviço prestado pela televisão esteja de acordo com a normatividade. Há expectativa social de que assim se dê e de que os operadores de mídia assim ajam. É preciso que as empresas respeitem essa confiança do público. Todavia, a confiança da população na comunicação transmitida pode ser traída pelo desvio de finalidade, pela desobediência aos deveres laterais da boa-fé e por 
atropelo dos bons costumes. Nesses casos, há abuso de direito. A compreensão da ilicitude gerada por atropelo dos bons costumes, nessa matéria, é de mais fácil percepção a partir da classificação do dever de confiança como obrigação de garantia.

Fernandes Neto, com apoio em parecer de Fábio Konder Comparato, classifica o dever de confiança dos meios de comunicação social e de demais atores do sistema de comunicação como obrigação de garantia. Tal conceito descreveria melhor a situação desse dever, do que a tradicional dicotomia obrigação de meio - obrigação de resultado. Na obrigação de garantia, há eliminação de um risco que pesa sobre o credor: mesmo nas hipóteses de caso fortuito ou força maior o devedor assumirá a responsabilidade.

Os direitos da criança e do adolescente à formação integral são lesados continuamente por certos programas. Como a Constituição Federal, de 1988, e o Estatuto da Criança e do Adolescente atribuíram a todos os entes sociais o dever de dar atenção prioritária aos direitos infanto-juvenis, de todos se pode cobrar responsabilidade. É mais difícil configurar lesão por comissão do que por omissão, o que se verifica quando a programação televisiva atropela dispositivos legais de proteção dos direitos da criança e do adolescente. Aqueles que colaboram nesse resultado assumem também responsabilidade.

Conforme o art. 942 do Código Civil, de 2002, “os bens do responsável pela ofensa ou violação do direito de outrem ficam sujeitos à reparação do dano causado; e, se a ofensa tiver mais de um autor, todos responderão solidariamente pela reparação". A reparação não se limita a pagar um preço pelo ilícito no caso de atividade em continuidade. Inclui-se na reparação a interrupção da atividade lesiva.

\section{Tutela inibitória}

A simples ameaça de dano é suficiente para a tutela judicial. Possibilidade similar de proteção preventiva, em razão de ameaça a direito, pode ser identificada de modo amplo na previsão constitucional do art. $5^{\circ}, \mathrm{XXXV}$, e, no âmbito dos direitos personalíssimos, arts. 12 e 21 do Código Civil, de 2002.

Quanto ao caminho processual civil para viabilizar a tutela do direito da criança e do adolescente em face da televisão, as vias inibitórias têm especial interesse. Prevenir é melhor que remediar e, no caso da formação infanto-juvenil, é absolutamente necessário evitar a incidência de mal que possa repercutir negativamente na delicada conformação da pessoa humana, e marcar sua personalidade de modo gravoso. A tutela preventiva é a forma mais perfeita da via jurisdicional, pois protege os bens da vida, garantindo a satisfação de tais. Com a tutela preventiva pode-se evitar a evolução danosa, 
que medeia entre a circunstância perigosa e o efetivo prejuízo a direito. Opera-se desse modo a atualização do imperativo jurídico alterum non laedere. A reparação é prestação jurisdicional menos perfeita.

A tutela inibitória é espécie de tutela preventiva que previne o dano. $\mathrm{O}$ sistema jurídico oferece ao jurisdicionado para que possa proteger direito que corre o risco de não mais existir sem o auxílio de prestação judicial de urgência. Comumente essa tutela se realiza mediante provimentos de natureza mandamental, imperando-se a alguém a abstenção de conduta. Pode ser reconhecida nas normas expressadas nos arts. 287 e 461 , do Código de Processo Civil.

$\mathrm{O}$ art. 461 do CPC determina que "na ação que tenha por objeto o cumprimento de obrigação de fazer ou não fazer, o juiz concederá a tutela específica da obrigação ou, se procedente o pedido, determinará providências que assegurem o resultado prático equivalente ao do adimplemento". O $\S 1^{\circ}$ do art. 461 do CPC situa a tutela reparatória em segundo plano.

O termo obrigação, aqui empregado, está em sentido amplo e poderia vir grafado como dever. As emissoras de TV têm o dever de velar pelos interesses da criança e do adolescente e de se submeter à normativa do sistema protetivo nacional. Desde o Diploma Constituinte, democraticamente estabelecido, a sociedade política lhes sobrecarrega a responsabilidade de conduzirem o serviço público de radiodifusão de sons e imagens, segundo parâmetros que se coadunem à formação ética do público infantojuvenil, de modo que caiba a elas agirem de acordo com tal preceito.

Os operadores de mídia televisiva, sob tal exigência, deveriam exercitar sua liberdade de expressão e sua capacidade inventiva para compor soluções que integrassem os seus interesses com os interesses educativos de atenção particular à situação dos menores. No entanto, alguns profissionais desse setor adotam postura unilateral de defesa de privilégios.

A tutela judicial inibitória deve paralisar a evolução do ilícito. O abuso sinaliza o momento de atualizá-la, para garantir a prevenção de dano, cujos efeitos perniciosos sobre a personalidade em construção da criança e do adolescente jamais seriam compensados.

A tutela inibitória pode ser aplicada de modo autônomo, tendo por escopo, como sugere sua designação, inibir a destruição ou deterioração de direito que possa ser afetado pela continuidade do ilícito. Trata-se de ação de conhecimento autônoma. " $O$ direito à prevenção não pode ser considerado um acessório à reparação do dano. Isto 
significa que não há razão para se pensar que o direito à prevenção deve ser exigido por intermédio de ação cautelar".

Antes da previsão expressa da tutela inibitória ampla, apta a prevenir danos imateriais, Barbosa Moreira chamava a atenção para a anomalia no sistema processual, no qual se admitia inibição de ato ilícito que gerasse eventual prejuízo material - interditos possessórios - , mas não havia meio de impedir atitude que viesse a violar direito imaterial, como os direitos de personalidade. O caráter reparatório é sempre insuficiente em matéria de direitos de personalidade, o que torna o bem imaterial mais carecedor de tutela inibitória. O sistema processual dava primazia ao ter sobre o ser.

\section{Tutela judicial fundada no Código de Defesa do Consumidor}

Os bens imediatamente tutelados pelo microssistema do Código de Defesa do Consumidor têm natureza predominantemente econômica, enquanto as normas do microssistema da Comunicação Social e do Estatuto da Criança e do Adolescente estão na órbita sobretudo de direitos imateriais, como os direitos fundamentais, os direitos de personalidade e os direitos especiais da criança e do adolescente. No entanto, em razão de a TV comercial aberta estar voltada ao mercado de consumo, e de a tônica econômica publicitária condicionar sua programação, não é de todo impróprio valer-se das normas do Código de Defesa do Consumidor (doravante CDC) que mais se aproximam da tutela de bens imateriais, para subsumir as relações de comunicação social a esse diploma, como alternativa de tutela do direito à formação integral da criança e do adolescente.

Além disso, é necessário reconhecer a tutela de bens imateriais também no sistema do Código de Defesa do Consumidor. Esse fato é melhor percebido pela introdução da boa-fé objetiva como cláusula geral e pela coibição de cláusulas abusivas. Tais normas ultrapassam o caráter econômico e introduzem no Código de Defesa do Consumidor a tutela de bens imateriais relacionados à confiança nas relações jurídicas. Deve-se notar que o objeto imediato da boa-fé objetiva não é a garantia de uma satisfação creditícia, mas sim tutelar a confiança, a lealdade e demais condutas éticas que devem compor qualquer relação jurídica, em decorrência da dignidade das partes envolvidas. Sob essa perspectiva, apesar de o Código de Defesa do Consumidor estar relacionado à tutela da relação de consumo, portanto a um universo de valores materiais, nem por isso excluiu a apreciação e proteção do conteúdo de valor intangível que se sedimenta nas relações de consumo.

A tutela dos direitos difusos e coletivos posta no Código de Defesa do Consumidor, por outro lado, manifesta tutela de natureza social que extrapola interesses 
individuais. Dessa forma, dado o uso da publicidade na TV comercial aberta, é possível apoiar-se na normativa respectiva do Código de Defesa do Consumidor para proteger direitos afetados pela Comunicação Social de massa, quando voltada especialmente para finalidade publicitária, ou seja, orientada para valores de consumo.

A própria Lei dá essa abertura para a aplicação ampla do Código de Defesa do Consumidor ao dizer em seu artigo $1^{\circ}$ que "o presente código estabelece normas de proteção e defesa do consumidor, de ordem pública e interesse social, nos termos dos arts. $5^{\circ}$, inciso XXXII, 170, inciso V, da Constituição Federal [...]”. A moldura constitucional apresentada por esse texto relaciona o art. $5^{\circ}$, dedicado aos direitos fundamentais e o art. 170, inserido no capítulo "princípios gerais da atividade econômica", no qual se declara que a atividade econômica tem por fim "assegurar a todos existência digna, conforme os ditames da justiça social".

No corpo do Código de Defesa do Consumidor, destaca-se o art. 37 como de especial interesse para esse estudo, ao proibir toda publicidade enganosa ou abusiva, tendose como abusiva, segundo o $\S 2^{\circ}$, "a publicidade discriminatória de qualquer natureza, a que incite à violência, explore o medo ou a superstição, se aproveite da deficiência de julgamento e experiência da criança, desrespeita valores ambientais, ou que seja capaz de induzir o consumidor a se comportar de forma prejudicial ou perigosa à sua saúde ou segurança". Essa norma se aplica à publicidade televisiva de produtos e mesmo à programação televisiva, pois também os programas, na TV comercial aberta, são produtos de venda da emissora, que adquire audiência em troca deles, audiência que lhe permite aferir lucro e fixar os valores dos espaços publicitários.

$\mathrm{O}$ que se deduz do art. $37 \S 2^{\circ}$ ? Entre outras coisas, que se vedam estímulos a condutas contrárias aos valores sociais e éticos da pessoa e da família, e a manipulação da vulnerabilidade da criança e do adolescente. Ou seja, há sob tal preceito o dever de garantir o direito à formação integral em face da publicidade, reconhecendo-se sua força persuasiva.

Na seção II do capítulo que trata "da qualidade de produtos e serviços, da prevenção e da reparação dos danos", há dois artigos que também chamam a atenção. Primeiro, o art. 12, que atribui responsabilidade objetiva ao produtor, nacional ou estrangeiro, e ao importador, pela reparação dos danos causados aos consumidores "por defeitos decorrentes de projeto, fabricação, construção, montagem, fórmulas, manipulação, apresentação ou acondicionamento de seus produtos, bem como por informações insuficientes ou inadequadas sobre sua utilização e riscos". Publicidade e propaganda podem gerar riscos à integridade física, psíquica e moral da criança, assim 
como programação, que pode ser entendida como produto ou serviço, prevalecendo o termo de "serviço" na TV comercial aberta. Por exemplo, é dever das emissoras prestar informação acerca dos efeitos e da conveniência de determinada programação para o público infanto-juvenil.

Para aquilatar a assunção do telespectador à posição de consumidor, o art. 17 estabelece que se equipara a consumidor toda vítima do evento, assim como as pessoas expostas às práticas comerciais (art. 29, do CDC), especialmente quando consideradas hipossuficientes. O telespectador passa a ser o teleconsumidor nessa perspectiva de análise. "A informação passada [...] sem dúvida configura o produto essencial posto à disposição dos milhares de receptores da mensagem, que são os destinatários finais à luz do que dispõe o art. 29, do Código de Defesa do Consumidor".

Continuando sob a perspectiva do subsistema da publicidade, Guilherme Fernandes Neto reuniu quatro princípios a vincular a atividade dos operadores de meios de comunicação social de massa: (1) a boa-fé objetiva (também aplicável à propaganda governamental), (2) o ônus da prova a cargo do fornecedor, (3) a interpretação contratual mais favorável ao consumidor e (4) o princípio da vinculação.

A inversão do ônus da prova tem valia quando se atribui ao fornecedor de programa que atinge criança e adolescente o dever de provar que não contraria valores sociais e éticos da pessoa e da família, bem como sua perfeita sintonia com a normatividade do Estatuto da Criança e do Adolescente. Deve a autoridade judiciária ou administrativa verificar, na acusação feita por pais ou entidades que atuam para proteção dos direitos da criança e do adolescente, se há verossimilhança no fato narrado e hipossuficiência da parte que demanda (CDC, art. $\left.6^{\circ}, \mathrm{VIII}\right)$. Analogicamente seria defensável aplicar o disposto nos arts 36, § único do Código de Defesa do Consumidor, 38 e $37 \S 2^{\circ}$ (sobre publicidade), aos programas de TV, sempre que lesivos à criança e ao adolescente, uma vez que o art. 17 do Código de Defesa do Consumidor equipara à situação de consumidor todos aqueles que foram vítimas de fato do produto ou do serviço independentemente de terem remunerado diretamente o fornecedor: os programas de TV são produtos e serviços.

Reconhecido o telespectador infanto-juvenil como consumidor de programas, prestando sua audiência como moeda de troca, surge um largo caminho para fazer valer seus direitos em face das emissoras e retransmissoras de TV.

Na perspectiva do Direito do Consumidor, como ora se concebe, há responsabilidade dos meios de comunicação social pela exposição de publicidade e também pelo conteúdo dos programas de TV que geram danos imateriais. A relação de consumo impõe deveres quanto à qualidade do produto. Publicidade e programas de TV 
podem danificar a personalidade, no sentido psíquico, moral e, indiretamente, pelo forte estímulo a hábitos deletérios para a saúde, danos físicos. Maior a gravidade quando o consumidor está na "condição peculiar de pessoa em desenvolvimento" (ECA, art. 71: criança e adolescente).

A ameaça de dano pode ser aferida quando se pratica conduta vedada diretamente pelo ordenamento. A omissão lesiva se dá quando não se acolhe disposição do ordenamento que atenderia interesse próprio de criança e adolescente, o que, por sua vez, também ameaça direito. Ocorreria uma espécie de inadimplemento, em razão de o regime de concessão pública dos canais de TV e rádio, cujo conteúdo de programação, a despeito da liberdade de expressão, deve atender a finalidades predefinidas na Constituição Federal.

Nesse momento entram em campo os princípios anteriormente anotados.

O princípio da confiança tem sido apresentado como integrando as relações de consumo, bem como todo o universo das relações privadas, sejam ou não de caráter econômico, e sua não-observação enseja responsabilidade. A boa-fé objetiva reforça a responsabilidade e está presente em todo o sistema jurídico nacional, sendo localizada expressamente no Código Civil, de 2002 (art. 187, ao descrever situações que configuram o ato ilícito), no Código de Defesa do Consumidor (art. $4^{\circ}$, III) e, ainda, em matéria de Direito Público, na Lei Federal n. 9.784/99, que determina à Administração Pública seguir a probidade, o decoro e a boa-fé (art. $2^{\circ}, \S$ único).

Como informação derradeira, interessa notar que a normativa do art. 221, da Constituição Federal de 1988, aplicada à programação da radiodifusão de sons e de sons e imagens, foi expandida aos serviços eletrônicos de internet, por disposição da emenda constitucional n. 36, de 2002, que acresceu novo parágrafo $\left(\S 3^{\circ}\right)$ ao art. 222, dizendo-se que “os meios de comunicação social eletrônica, independentemente da tecnologia utilizada para a prestação do serviço, deverão observar os princípios enunciados no art. 221, na forma de lei específica [...]". Trata-se também de assunto que demanda nova tese.

\section{Ação civil pública}

A restrição ao exercício do direito fundamental de liberdade de expressão decorre da garantia de interesses de idêntico caráter. São a contraface de outro direito fundamental. Em razão disso, as restrições têm eficácia normativa instantânea $(\mathrm{CF}$, art. $5^{\circ}, \S 1^{\circ}$ ). Os interesses metaindividuais da criança e do adolescente, que restringem a liberdade de expressão na televisão comercial aberta, equiparam-se a direitos fundamentais, 
e autorizam as entidades representativas a se valerem dos meios disponíveis para protegêlos.

O direito fundamental à formação integral em face da televisão, tem a ação civil pública como a mais apropriada garantia judicial de defesa, uma vez que o interesse é metaindividual. Na atualidade, o Ministério Público é o agente melhor qualificado para promover essa ação, e tem acumulado experiência nessa matéria.

Todavia, a legitimidade para propor ação civil pública foi dada também a “pessoas jurídicas de Direito Público interno, associações e outras entidades - desde que seu objeto fosse a tutela de interesses difusos ou coletivos".

Mazzilli diferencia duas categorias de interesse público, apoiando-se nas idéias de Renato Alessi: interesse público primário e secundário. Interesse público primário seria o bem geral, interesse da coletividade como um todo. Por interesse secundário, tem-se o interesse público na perspectiva dos mandatários que ocupam cargos eletivos e governam o Estado em cada época. Essa distinção é importante em razão de eventuais divergências entre a percepção do bem comum segundo a perspectiva da sociedade civil, representada pelo Ministério Público, e o ponto de vista dos mandatários que ocupam os cargos públicos eletivos. "Confundem-se antes com o interesse público primário os mais autênticos interesses difusos (o exemplo, por excelência, do meio ambiente); e, num sentido lato, também os interesses que, posto reflexamente, atinjam toda a sociedade (nesse sentido até mesmo interesse individual, se indisponível, deve ser considerado interesse público)". O Ministério Público tem legitimidade extraordinária para, em nome próprio, defender judicialmente interesse público (CPC, art. $\left.6^{\circ}\right)$.

A programação televisiva se configurar-se-ia como interesse difuso ounão?

Barbosa Moreira entende que sim, por subsumir a situação aos termos do art. 81, I ou II, do Código de Defesa do Consumidor. O art. 81, I, define direito difuso como o direito transindividual de natureza indivisível, pertencente a pessoas indeterminadas, ligadas por circunstâncias de fato. O art. 81, II, define direito coletivo como direito transindividual de natureza indivisível cujo "seja titular grupo, categoria ou classe de pessoas ligadas entre si ou com a parte contrária por uma relação jurídica base".

A diferença peculiar do direito coletivo com relação ao interesse difuso está na circunscrição das pessoas. A programação de TV é bem indivisível de interesse transindividual, assumindo, nesse particular, caráter de direito difuso ou coletivo. Não é possível dividir a programação transmitida. Além disso, ela é dirigida a elevado número 
de telespectadores. Parece ser esse o melhor entendimento e isso vem evidenciado na aceitação jurisprudencial do fenômeno.

Poderia alguém objetar que há interesse difuso na assistência a cenas de violência e sexo, conforme se deduz da audiência de programas que apelam a essas situações. A esses, Barbosa Moreira responde que ainda que haja grande contingente que se renda a tais conteúdos, a Constituição Federal, de 1988, tomou partido e definiu $a$ priori que tais não prevaleceriam (interpretação a contrario sensu do art. 221), deixando a critério dos demais usar de outros recursos para satisfazer seus instintos menos nobres via TV e rádio.

E se a objeção viesse fundada no impedimento de censura? Responde o mesmo jurista que não se pode nomear de censura a restrição da liberdade de expressão (direito-meio), especificada na Constituição e autorizada para atendimento de direitos fundamentais que dão guarida à dignidade humana (princípio ou valor-fim). A Constituição não pode tolerar afronta ao valor absoluto da dignidade humana. Se órgãos administrativos comandados por pessoas nomeadas pelo Executivo, em cargos de comissão, não podem exercer essa tarefa, há outros meios disponíveis, destacando-se a atuação do Judiciário em defesa dos direitos fundamentais. Uma vez que é função do juiz cumprir a lei e a Carta Maior é seu guia de atuação, está ele obrigado a atender aos reclamos dos cidadãos com apoio na Constituição. Dessa forma caberá a ele preencher os conceitos abertos do art. 221 em cada caso, como sói fazer em situações de leis construídas com conceitos de sentido vago, para maior flexibilidade decisória. Não se pode nomear essa atividade de censura.

É fato que melhor delineamento normativo infraconstitucional facilitaria a aplicação das disposições do art. 221, da Constituição Federal, de 1988. Deveria o Legislativo manifestar-se expressamente sobre os dispositivos do art. 221, para atender à demanda de normas que norteiem o debate jurisdicional acerca da constitucionalidade ou inconstitucionalidade de determinado entendimento. Ao mesmo tempo, deve-se evitar a postura de espera de uma "regulação pelo mercado", se a Constituição não previu esse procedimento. Em face de sua omissão, por vezes grupos de pressão econômicos (lobbies) terminam por impor seus interesses por vias diversas do espírito democrático. Nesse sentido, cabe ao Ministério Público propor interpretação das normas constitucionais e cabe ao Judiciário manifestar-se sobre sua aplicação. Essa tem sido a praxe. Não fosse imediata a aplicação da norma constitucional, a sociedade civil se tornaria refém do interesse particular de grupos de parlamentares que pretendem manter a situação de modo indefinido, por serem empresários do setor. "Grande parte da torta já está repartida entre os comensais e ainda o legislador não se decidiu a servi-los na mesa". 


\section{Conclusão}

Pôde-se apresentar nesse artigo recursos disponíveis para os cidadãos reagirem em face dos abusos da programação de TV, perpassando compreensão do dano moral e perspectivas diversas de meios judiciais aptos a forçar o cumprimento do dever legal dos concessionários de radiodifusão a cumprirem sua missão de agentes de formação ética dos telespectadores infanto-juvenis.

Dos variados meios de constranger essa realização, a ação civil pública ainda é o melhor instrumento judicial, pelas razões acima apontadas. Contam-se importantes ações civis públicas movidas entre os anos 2000 e 2005, no Brasil, em face de emissoras de televisão que ofenderam direitos do público infanto-juvenil. Vale a pena conhecê-las.

São Paulo, novembro de 2007.

\section{Referências}

FARACO, Alexandre Ditzel. Controle da qualidade da radiodifusão: mecanismos de aplicação do artigo 221, IV, da Constituição Federal. Revista de Direito Público da Economia, Belo Horizonte, v. 4 n. 14, p. 7-36, abr./ jun. 2006.

FERNANDES NETO, Guilherme. Direito da comunicação social. São Paulo: Revista dos Tribunais, 2004.

JABUR, Gilberto Haddad. Efeitos Jurídicos da ameaça ou lesão a direitos personalíssimos por fato de comunicação social. 2005. Tese (Doutorado) - Pontifícia Universidade Católica, São Paulo.

MANCUSO, Rodolfo de Camargo. Controle jurisdicional do conteúdo da programação televisiva. Revista dos Tribunais, São Paulo, v. 90, n. 793, p. 89-102, nov. 2001.

MARÍAS, Julián. Tratado de lo mejor. La moral y las formas de la vida. 1. ed. 4. reimp. Madrid: Alianza Editorial, 1996.

MARINONI, Luiz Guilherme. Tutela inibitória (individual e coletiva). 3. ed. São Paulo: Revista dos Tribunais, 2003.

MAZZILLI, Hugo Nigro. A ação civil pública no Estatuto da Criança e do Adolescente. Revista dos Tribunais, São Paulo, v. 79, n. 659. p. 36-9, set. 1990.

MOREIRA, José Carlos Barbosa. Ação civil pública e programação de TV. Revista de Direito Administrativo, Rio de Janeiro, n. 201, p. 45-56, jul./set. 1995. 
. Tutela sancionatória e tutela preventiva. In: Temas de direito processual. 2. série. São Paulo: Saraiva, 1980.

PEREIRA JÚNIOR, Antonio Jorge. $O$ direito da criança e do adolescente à formação integral em face da TV comercial aberta no Brasil: o poder-dever de educar em face da programação televisiva. 2006. Tese (Doutorado) - Faculdade de Direito, Universidade de São Paulo, São Paulo.

PIERRI, Deborah; SOUZA, Motauri Ciocchetti; NUNES JÚNIOR, Vidal Serrano. Promotores de Justiça do Ministério Público do Estado de São Paulo. Ação Civil Pública movida em face da MTV, em 25 de outubro de 2002, para proteger direitos da criança e do adolescente em razão de propaganda subliminar de conteúdo sexual.

PODESTÁ, Fábio Henrique. Interesses difusos, qualidade da comunicação e controle judicial. São Paulo: Revista dos Tribunais, 2002.

ROCA, Javier García. Limites constitucionales al legislador de la televisión. Cadernos de Direito Constitucional e Ciência Política, São Paulo, v. 6, n. 22, p. 7-37, jan./mar. 1998.

ROCHA, Teresa Maria do Nascimento. A tutela judicial dos interesses metaindividuais da criança e do adolescente. 2003. Dissertação (Mestrado) - Faculdade de Direito, Universidade de São Paulo, São Paulo.

SAVATIER, René. Traité de la responsabilité civile. 2. ed. Paris: L.G.D.J., 1951. v. 2.

SILVA, Oscar José de Plácido e . Vocabulário jurídico. Rio de Janeiro: Forense, 1987. v. 1. 